Ankara Üniversitesi Türk Inkılâp Tarihi Enstitüsü Atatürk Yolu Dergisi

S 33-34, Mayıs-Kasim 2004, s. 89-101

\title{
Cumhuriyetin Onuncu Yıldönümü Kutlamaları ve 26 Ekim 1933 Tarihli Genel Af Yasası
}

\author{
Dr. Cahide SINMAZ-SÖNMEZ
}

\begin{abstract}
$\ddot{O} z e t$
Cumhuriyetin onuncu yıldönümü pek çok açıdan önem arz etmektedir. Geçen on yıl zarfinda, Türkiye Cumhuriyeti Devleti, modern, çağdaş ve laik bir devlet olma yolunda önemli adımlar atmıştır. Böylesine kısa bir zamanda, uzun bir yol kat edilmiş olması, gerek idarecilerde gerekse halkta onuncu yıl kutlamalarının daha farklı yaşanması isteğini uyandırmış ve bu sebeple de pek çok etkinlikler düzenlenmistir. Bu etkinlikler arasında bulunan genel af yasası da on yıllık dönemde yaşanan olumsuz izlerin silinmesi ve uygulanan katı politikaların yumuşatılarak bir normalleştirme sürecine girilmesi açısından son derece önemli bir rol oynamıştır. Bu araştırmanın konusunu da Cumhuriyetin onuncu yıldönümü kutlamaları çerçevesinde çıkarılan bu genel af yasası oluşturmaktadır.
\end{abstract}

Anahtar Kelimeler: Cumhuriyet, Onuncu Yıl, Kanun, Genel Af, İç Politika

\section{Celebration of Tenth Anniversary of The Republic And The Amnesty of October $26^{\text {Th }} 1933$ \\ ABSTRACT}

Tenth anniversary of the Republic presents importance from numerous aspects. In the past ten years time, the Republic of Turkey had taken significant steps in becoming a modern, contemporary and secular state. Taking such a long course in a very short time had created both within the administrators and the public a desire to experience the tenth anniversary celebration in a different way and as a result a lot of activities had been organized. The amnesty act, which was one of those activities, had played an important role in deleting the negative traces experienced in this ten

\footnotetext{
'Çanakkale Onsekiz Mart Üniversitesi, Fen-Edebiyat Fakültesi, Tarih Bölümü.
} 
years period and in entering into a normalization period by softening the rigid policies applied. This amnesty act taken into effect within the celebration of the tenth anniversary of the Republic constitues the subject of this study.

Key Words: Republic, Tenth Year, Law, Amnesty, Internal Policy

Cumhuriyetin onuncu yıldönümü daha önceki dönemlerden farklı olarak, büyük bir görkem ve coşkuyla kutlanmıștır. Cumhuriyetin ilanından itibaren geçen on sene zarfında, genç cumhuriyetin çehresi değişmiş, her alanda girişilen hamleler ve yapılan inkılaplarla böylesine kısa bir sürede, büyük bir yol kat edilmiştir. Tarım ve sanayi alanlarındaki düzenlemeler, ülkenin iktisadi yönden kalkınmasını sağlarken, sosyal alanda girişilen inkılap hareketleri ise modern bir toplumun oluşmasını sağlamıştır. Eğitim ve kültür alanlarında yapılan yenilikler de çağdaş ve laik bir modelin oluşmasında öncülük etmiştir. Dış politikada, Türkiye Cumhuriyetinin izlediği dostluk ve barış politikası, Türkiye'yi dünyada tanınan, saygı duyulan bir devlet konumuna getirdiği gibi, iç politikada yaşanan, çok partili hayata geçiş denemelerinin ardından girişilen otoriteyi güçlendirici uygulamalar, on yılı geride bırakan Cumhuriyetin sağlam temellere oturduğunu göstermiştir.

Genç Cumhuriyetin böylesine kısa bir zamanda aldığı yolun bütün yurtta idrak edilmesi ve bu başarıların tüm dünyaya duyurulması isteği, cumhuriyetin ilanının onuncu yıldönümü kutlamalarına farklı bir anlam kazandırmış, bu nedenle her zamankinden farklı olarak, Cumhuriyet Bayramını kutlama etkinlikleri, Ekim ayından çok önce başlamıştır. Malatya Mebusu Abdülmuttalip, Denizli Mebusu Necip Ali, Giresun Mebusu Hakkı Tarık, Bolu Mebusu Hasan Cemil ve Muş Mebusu Hasan Reşit Beyler, bir kutlama programı oluşturmak üzere, 9 Haziran 1933 tarihinde "Cumhuriyet İlanının Onuncu Yıldönümünü Kutlama Kanunu” başlıklı bir kanun teklifini, Meclis Başkanlığına sunmuşlardır. ${ }^{1}$ Sadece geçmişin şerefli ve başarılı günlerine yönelik bir teşekkür mahiyetinde olmayıp, aynı zamanda gelecek nesiller için yeni bir başlangıç yapmak arzusuyla oluşturulduğu ifade edilen, 12 maddelik bu kanun teklifiyle; Cumhuriyetin onuncu yılının kutlanacağı Cumhuriyet Bayramı kutlamalarında, halkın ve hükümetin alacakları sorumluluklar belirlenmiş ${ }^{2}$ ve TBMM'nin 11 Haziran 1933 tarihli birleşiminde aciliyetle görüşüldükten sonra yasalaşan bu kanunla; Cumhuriyetin onuncu yıldönümünün üç gün süreyle kutlanacağı kararlaştırılmıştır. ${ }^{3}$

Bayram hazırlıkları, gazetelerin sayfalarında ekim ayı boyunca büyük manşetlerle duyurulmuştur. Onuncu yıl şerefine özel pullar hazırlandığı

'Türkiye Büyük Millet Meclisi Zabıt Ceridesi, Devre 4, Cilt 16, s. 212, Sıra Sayısı: 315.

${ }^{2}$ TBMM Z.C., D. 4, C. 16, Sira Sayısı: 315, s. 1-2.

${ }^{3}$ TBMM Z.C., D. 4, C. 16, s. 185-186; Düstur, Devre 3, Cilt 14, s. 1531. 
gibi, ${ }^{4}$ Ziraat Bankası da üzerinde Atatürk'ün resmi olan madalyalar bastırmış̧ır. ${ }^{5}$ Ayrıca bu kutlamalar çerçevesinde; cumhuriyetin on yıl içerisinde geçirdiği evrelerin de anlatıldığı pek çok konferanslar düzenleneceği ve bu konferansların nerelerde kimler tarafından verileceği haberlerinin yanı sıra, pek çok şehirde Cumhuriyet Baloları düzenleneceği, basın organları aracılığıyla halka duyurulmuștur. ${ }^{6}$ Bayram süresince İstanbul ve Ankara gibi büyük şehirler daha önce örneği görülmemiş şekilde taklarla süslenmiş, şehirlerin çeşitli yerlerine yerleştirilen projektörlerle aydınlatma sağlanmıştır. Hükümet de, kutlamaların devam edeceği süre zarfında pek çok alanda halka destek olmak amacıyla çeşitli düzenlemeler yapmıştır. Örneğin, Onuncu Yıl kutlama programının belirlendiği kanunla; bayramdan on gün önce başlamak ve bayram günleri ile sonraki on gün sürmek üzere devletin ulaştırma araçları tarifelerini indirebileceği tespit edilmiş olduğundan, Devlet Demir Yolları ve Liman İşletmeleri Umum Müdürlüğü seferlerini, 19 Ekim-10 Kasım tarihleri arasında indirimli olarak yapacağını açıklamıştır. Devlet kurumları yanında, kutlamalar süresince bir çok kişi vaktini sokaklarda geçireceğinden, vatandaşın yemek ihtiyacını rahatlıkla giderebilmesi düşüncesiyle lokantalar da indirim yapma kararı almışlardır. ${ }^{8}$

Cumhuriyetin onuncu yıldönümünü kutlamaları, büyük halk kitlelerinin katılımıyla olağanüstü bir coşku ve heyecan içerisinde gerçekleştirilmiştir. Bayram kutlamaları gazetelerin sayfalarını süsleyen en önemli haberler olurken, bütün gazeteler 29 Ekim günü Cumhuriyetin on yıllık serüvenini anlatan fevkalade nüsha yayınlamışlardır. ${ }^{9}$ Bayramın pek çok şehirde nasıl kutlandığını bildiren haberlerin yanı sıra resimlere de yer verilmiş ve halkın yaşadığı coşku, basın organları aracılığıyla gözler önüne serilmiştir. Pek çok yerleşim merkezlerinden haberler verilirken, İstanbul, Ankara ve İzmir'deki törenlerin görkemi ön sıraları almış ve Ulu Önder Gazi Mustafa Kemal'in Onuncu Yıl Nutku, tam metin olarak gazetelerde yayınlanmıştır. Daha önce emsali görülmemiş bir şekilde süslenen ve bayrama hazırlanan İstanbul'da ise Cumhuriyet Bayramının kutlandı $\breve{g}_{1}$ meydanlar o tarihten itibaren Cumhuriyet Meydanı olarak adlandırılmaya başlanmış, örneğin; Beyazıt Meydanının adı Cumhuriyet Meydanı olarak değiştirilmiştir. ${ }^{10}$ Cumhuriyetin Onuncu yıldönümü yurt içinde olduğu kadar, Türk elçiliklerinde de büyük bir coşkuyla kutlanmış, verilen ziyafetlere yabancı ülke cumhurbaşkanları ve başbakanları bizzat katılmışlardır. ${ }^{11}$

\footnotetext{
${ }^{4}$ Hakimiyet-i Milliye, 17 Ekim 1933.

${ }^{5}$ Milliyet, 22 Ekim 1933.

${ }^{6}$ Hakimiyet-i Milliye, 24 Ekim 1933; Milliyet, 25 Ekim 1933.

${ }^{7}$ Hakimiyet-i Milliye, 20 Ekim 1933.

${ }^{8}$ Cumhuriyet, 25 Ekim 1933.

${ }^{9}$ Akşam, 29 Ekim 1933.

${ }^{10}$ Cumhuriyet, 24 ekim 1933; Milliyet, 31 Ekim 1933.

"Cumhuriyet, 1 Kasim 1933.
} 
Bu büyük kutlamalar çerçevesinde yabancı ülke temsilcileri de törenlere katılmak üzere Türkiye'ye davet edilmiş ve Başkent Ankara'daki törenlere Mareşal Varoşilof Başkanlığında Mareşal Budiye'nin dahil olduğu Sovyet Rusya Heyetinden başka; Yunanistan adına Hava Kuvvetleri Komutanı General Adamides, Almanya adına Moskova Büyükelçisi Her Nadalny, Bulgaristan adına Maarif Nazırı Boyaciyef ve General Narkaf, Romanya adına Ayan Meclisi üyeleri Ahmet Taşçı ve Mustafa Beylerle, Silistre Müftüsü Hafız Rıfat Efendi katılmışlardır. Bu durum, onuncu yıl kutlamalarına ilgi gösteren yabancı basının ilgisini daha da arttırmıştır. Türkiye Cumhuriyetinin geçen on yıl zarfında yarattığı yeni çehre yabancı yayın organlarında dile getirilmiş, bu değerlendirmeler, Türkiye'de yayınlanan basın organları vasıtasıyla da Türk halkına iletilmiştir. Bu haberler arasında, Gazi ve Cumhuriyeti öven makalelerle birlikte, yabanc1 ülke başkanlarının, Cumhuriyetin onuncu yılını tebrik mesajları, "Bütün Dünya Bayramımızı Tebrik Ediyor" gibi manşetlerle yer almıştır. Özellikle Viya, Londra, Times, Svesda ve Le Jurnal Gazetelerinin başmakaleleri yayınlanarak, çeşitli Dünya başkentlerinde Cumhuriyetin Onuncu yıldönümünün nasıl değerlendirildiği hakkında haberler verilmiştir. ${ }^{12}$ İngiliz basını da Cumhuriyetin onuncu yıl dönümü münasebetiyle, Kemalist reformların genel bir değerlendirmesini yapmak yolunu seçmiştir. Hemen bütün İngiliz gazetelerinde Türkiye ve Gazi Mustafa Kemal hakkında yazılar yayınlanmış olup, Dailiy Telegraph Başmakalesinde; Mustafa Kemal Paşa'yı yeni Türkiye'nin yaratıcısı olarak tanımlamış ve Mustafa Kemal'i XIV. Louis ve Mussolini'ye benzeterek, onun sayesinde “Avrupa'nın hasta adamının, Yakın Doğu'nun küçük Herkülü”" olduğunu vurgulamıştır. ${ }^{13}$

Yabancı ülke liderleri de bizzat Gazi Mustafa Kemal'e gönderdikleri mesajlarla Türk halkının Cumhuriyet Bayramını kutlamışlardır. Liderlerin bazılarının şahsen, bazılarının ise dışişleri temsilcileri veya dışişleri kanalı ile Gazi'ye gönderdikleri Cumhuriyet Bayramı mesajlarına karşılık Gazi Hazretleri de mukabelede bulunmuş ve bütün dünyanın Türkiye Cumhuriyeti Devleti'ne gösterdiği ilgiden duyduğu memnuniyeti ifade etmiştir. ${ }^{14}$

Yukarıda bahsetmiş olduğumuz genel kutlama etkinliklerinin yanı sıra, geçmiş dönemde yaşanmış acı tecrübelerin unutulması ve alınan sert tedbirlerin ardından, bir normalleştirme sürecinin başlaması amacıyla, Hükümet, Cumhuriyet Bayramının öncesinde, bir af kanunu tasarısı hazırlayarak, 25 Ekim 1933 tarihinde Meclis Genel Kuruluna sunmuştur. Adliye Encümenine gönderilen kanun tasarısının, daha önceden İzmir Mebusu Mahmut Esat Bozkurt'un, basın suçlarının affına dair olarak vermiş

\footnotetext{
${ }^{12}$ Hakimiyet-i Milliye, 29 Ekim 1933; Milliyet, 30 Ekim 1933; Akşam, 30 Ekim 1933.

${ }^{13}$ Mustafa Yılmaz, Ingiliz Basını ve Atatürk'ün Büyük Türkiyesi, Phoenix Yayınları, Ankara, 2002, s. 93'den naklen; Daily Telegraph, 28 Kasım 1933.

${ }^{14}$ Atatürk'ün Tamim. Telgraf ve Beyannameleri, C. IV, Atatürk Araştırma Merkezi Yayını, Ankara, 1991, s. 622-625.
} 
olduğu kanun teklifiyle ${ }^{15}$ birleştirilerek müzakere edilmesi Adliye Encümenince kabul edilmiştir. Bu uygulama sayesinde kanun tasarısının kapsamı da genişletilerek, Hükümet tarafından 17 madde olarak hazırlanmış tasarı, ${ }^{16}$ Adliye Encümeni tarafından yapılan eklerle 19 madde olarak Meclis gündemine gelecektir. ${ }^{17}$

Hükümetin Cumhuriyetin Onuncu yılı nedeniyle bir af kanunu tasarısı hazırladığı haberleri basının gündeminde de yer almıștır. Daha çok duyuru niteliğinde olan bu haberlerde; affın siyasi mahkumlara yönelik olarak çıkarılacağı , Lozan Barış Antlaşmasıyla belirlenen 150 kişinin ise bu aftan istifade edemeyeceği konu edilmiștir. ${ }^{18}$ Basının tasarıya ilgi göstermesi ve bu konuda haberler yayınlaması nedeniyle, çıkarılması düşünülen af kanununu suistimal etmek isteyen bazı kişilerin ortaya çıktığını ve Hükümetin affın suistimalini önlemek için bir tebliğ yayınladığını görüyoruz. Hakimiyet-i Milliye Gazetesinin baş sayfasında "Af Kanunu Fikri Etrafinda Resmi Tebliğ” başlığıyla yayınlanan haberde; "Dahiliye Vekaletinden resmen tebliğ

${ }^{15}$ Mahmut Esat Bozkurt'un hazırladığı basın suçlarının affını öngören kanun teklifine göre; "matbuat suçlarından dolayı haklarında takibat yapılmakta olanlarla mahkum edilmiş bulunanların cürümleri affedilmiştir" TBMM Z.C., D. 4, C. 17, 26. 10. 1933, Sıra Sayısı: 363, s. 5 .

${ }^{16}$ TBMM Z.C., D. 4, C. 17, 26. 10. 1933, Sira Sayıs1: 363, s. 8-10.

${ }^{17}$ TBMM Z.C., D. 4, C. 17, 26. 10. 1933, Sıra Sayısı: 363, s. 13-15.

${ }^{18}$ Milliyet, 22 Temmuz 1933; Lozan Barış Antlaşması'na bağlı VIII. Ekte yer alan Genel Affa yönelik Beyannameye bağlı protokolde, Türk Hükümeti tarafından vatan haini olarak kabul edilmiş olan 150 kişi, tarafların karşılıklı olarak ve eşit şartlarda çıkarmayı taahhüt ettikleri genel af beyannamesi dışında bırakılmıştır. Bu protokolde, Türk Hükümeti, belirlediği 150 kişinin ülkeye girmesini ve orada oturmasını yasaklama hakkını saklı tuttuğunu ve böylelikle söz konusu kişilerden bugün ülkesinde bulunanları çıkarabilme, Yurt dışına gönderebilme yetkisine sahip olduğunu belirtmiştir. Antlaşmanın Genel Affa Yönelik Metni için Bkz. İsmail Soysal, Tarihçeleri ve Açıklamaları Ile Birlikte Türkiye'nin Siyasal Antlaşmaları, C. I (1920-1945), 2. Baskı, Türk Tarih Kurumu Yayını, Ankara, 1989, s. 187190; 150 kişinin genel aftan istisna tutulması ve bu kişilerin kimler olacağının belirlenmesi konusu, Cumhuriyet tarihinde önemli tartışmalar yaşanmasına sebep olmuş ve bu olay yakın tarihe "150'likler Meselesi" olarak geçmiş olup, af kapsamı dışında tutulan 150'likler, 8 başlık altında toplanmıştır: 1- Sultan Vahdettin, hanedan yasasıyla yurt dışına çıktığından onun listeye alınamayacağı, ancak, bütün icraatına yakından katılmış beş-altı kişi, 2- Sevr Antlaşması'nı imzalayan Kabine, 3- Kuvay-1 İnzibatiye'yi teşvik eden kabine, 4- Çerkes Ethem ve yandaşları, 5- Çerkes Kongresi'ni düzenleyen delegeler ve katılımcıları, 6- Milli Mücadele döneminde Anadolu direnişini baltalayan çete liderleri, 7- Ülke sınırları dışında bir takım İhtilal Komitelerini yöneten adamlar, 8- Milli Kurtuluş Savaşı aleyhinde bulunmuş İstanbul ve Taşra basın mensupları. Listeye dahil olan şahıslarla ilgili ayrıntılı bilgi için bkz. Cemal Kutay, 150'likler Faciası, Sıralar Matbaası, İstanbul, 1955; İlhami Soysal, 150'likler, Gür Yayınları, İstanbul, 1985; Sedat Bingöl, Yüzellilikler Meselesi, Yayınlanmamış Yüksek Lisans Tezi, Hacettepe UUniversitesi, Atatürk İlkeleri ve İnkılap Tarihi Enstitüsü, Ankara, 1994; Nurşen Mazıcı, “Af Yasalarında 150'likler”, Ankara Üniversitesi Siyasal Bilgiler Fakültesi Dergisi, C. 55, S. 1, Ankara, Ocak-Mart 2000, s. 86; 150'likler 1938 tarihine kadar çıkarılmış olan af yasalarının dışında bırakılmışlar, ancak 29 Haziran 1938 tarihli "Affı Umumi" kanunuyla affedilmişlerdir. Düstur, D. 3, C. 19, s. 779. 
edilmiştir: Cumhuriyetin 10. Yıldönümü münasebetiyle umumi af ilan edileceğinin gazetelerde görülmesi üzerine bazı kötü düşünceli şahısların hasımlarından öç almaya ötekini, berikini tahrik ettikleri işitilmektedir. Af için hükümet meclise bir teklifte bulunmamıștır. TBM Meclisi'nin bu hususta nastl bir karar vereceğini tahmin etmek mümkün değildir. Fakat umumi af dahi olsa şirretlerin af kanununu kötü maksatlarına alet yapmamaları için kayıtlar konacă̆ $ı$ ve herhalde affin 1933 yılbaşından beri yapılan cürümlere şamil olmayacağı muhakkaktır" ${ }^{\prime 19}$ açıklaması yapılarak, affın suça teşvik edici bir rol halini almasının önüne geçilmeye çalışılmıştır. Zira, af kanunlarının en çok eleştirilen noktalarından birisi; kişileri suça teşvik edebilme ihtimalidir. Hükümetin yayınladığ 1 bu tebliğ, devletin çıkaracağı afla ilgili olarak hassasiyetini ortaya koyması bakımından önemli bir girişimdir.

Hükümet hazırlamış olduğu af kanunu tasarısının gerekçesini; "Türkiye Cumhuriyeti Devleti onuncu yılını kutlarken, Türk inkılabının bu çok kısa bir devre içinde daima ileri atıllşlarla elde ettiği ve bütün medeni cihanın hayranlıkla gördüğ̈̈ siyasi ve içtimai muvaffakiyetlere vekar ve iftiharla bakmaktadır... Böyle mesut bir yil dönümünü kutlarken muhtelif sebep ve tesirlerle; ihtiras ve hatalarina kurban olmus, kanuni cezalarla mahkum olmuş, kimseleri de düşünmek, onları bir kıymet olarak tekrar cemiyetin sinesine almak muvafik olur. Bu biçarelere karşı gösterilecek müsamaha; kendilerini temiz bir unsuru istihsal olarak alacak olan cemiyet lehine bir hareket olduğu kadar memleketin haiz olduğu kuvvetin de bir delili olacaktır" ifadeleriyle açıklamıştır. ${ }^{20}$

Görülmektedir ki; Hükümet, Cumhuriyetin gücünü ve sağlamlığını tüm dünyaya duyurmak hedefini, çıkaracağı af kanunuyla da perçinlemek istemiştir. Hükümetin bu gerekçesi, Joseph Barthelemy'nin genel af hakkındaki; "Genel af, rejimin kuvvetinin bir delili olmalıdır. Genel affi teklif eden veya bunu kabul eden bir rejim, kendisine olan güvenini göstermiş bu suretle halka itimat telkin etmiş olacaktır" ${ }^{21}$ değerlendirmesiyle de paralellik göstermektedir.

Hazırlanan tasarıyla; bazı suçlar hakkında takibat yapılmayacağı, bazı cezalarda ise indirime gidileceği belirlenmiştir. Tasarının 8. maddesine göre; İstiklal Mahkemeleri tarafından mahkum edilen Terakkiperver Cumhuriyet Fırkası ve İzmir Suikastı mahkumlarının cezaları tamamen affedilecektir. Bunların dışında basın suçlarında takibat yapılmayacak, eğer her hangi bir ceza alınmıșsa, alınan ceza çektirilmeyecektir. Yasa, kanun kaçağı olanlar hakkında da bir düzenleme getirmekte ve bu gibi kişilerin, af kanunundan

${ }^{19}$ Hakimiyet-i Millive, 28 Temmuz 1933.

${ }^{21}$ TBMM Z.C., D. 2, C. 17, 26. 10. 1933, Sira Sayısı, 363, s. 6.

${ }^{21}$ Selahattin Keyman, Türk Hukukunda Af, Genel Af-Özel Af, Ankara, 1965, s. 25'den naklen; Joseph Barthelemy, L'Amnistie, Extrait de la Revue de Droit Public et de la Sciencce Politique en France et I'Etranger, N. 2, 1920, s. 7. 
yararlanabilmeleri, üç ay içerisinde teslim olmaları şartına bağlanmaktadır. Kanun, 28 Temmuz 1933 tarihine kadar işlenmiş olan suçlar için geçerli olacaktır. Hilafetin kaldırılması ve Osmanlı hanedanının yurt dışına çıkarılmasına dair olan 431 sayılı kanundaki şahıslar ile Lozan Antlaşmasıyla belirlenmiş olan 150 kişi ise bu affın dışında tutulacaklardır. Hükümet ayrıca, sunduğu tasarıda, "af tedbiri ne kadar geniş olsa bile cemiyetteki vazifeleri ve ahlaki temayülleri itibariyle bu affa mazhar olmaya layık olmayanlar" olduğu gerekçesiyle bazı suçları affın dışında bırakmıştır. ${ }^{22}$ Buna göre; zimmet suçu, rüşvet almak, müzayedeye fesat karıştırmak ve kaçakçılık suçlarından mahkum ya da tutuklu bulunanların aftan istisna edildiği tasarıda, hırsızlığı meslek haline getirmiş olanlarla, belirtilen suçların her hangi birisinden ikiden fazla mahkum olanların da bu aftan yararlanamayacakları belirtilmiştir. Dahiliye Vekili Şükrü Kaya Bey'in de ifade ettiği gibi, memleketin güvenliği açısından, yağmacılık, yol kesmek ve adam kaçırmaya yönelik suçlardan her hangi birisi ile mahkum veya sanık bulunanla da bu affın dışında tutulan suçlar arasına alınmıştır. ${ }^{23}$

Hükümetin, belirtmiş olduğumuz esaslar çerçevesinde sunduğu kanun tasarısının, Cumhuriyetin onuncu yıl kutlamaları çerçevesinde gelecek olan yabancı misafirlere, Türkiye Cumhuriyeti Devleti'nin kısa zamanda aldığı yolu ve rejimin kendine olan güvenini göstermek amacıyla, 29 Ekim tarihinden önce çıkarılması düşünülmüş ve tasarının acilen görüşülmesi için Afyon Karahisar mebusu Ali Bey tarafından bir önerge verilmiştir. ${ }^{24} \mathrm{Bu}$ önergenin kabulü sonrasında, kanun tasarısı Meclisin 26 Ekim 1933 tarihli 76. birleşiminin 2 . oturumunda görüşmeye açılmıştır. ${ }^{25}$

Denizli mebusu Emin Aslan Bey'in, aftan yararlanacak bazı kişilerin, vatandaşın huzur ve emniyetini bozabileceği endişesini dile getirmesiyle başlayan tartışmalar, ${ }^{26}$ Dahiliye Vekili Şükrü Kaya Bey'in yağmacılık, ev basmak, yol kesmek gibi suçların affın dışında bırakıldı̆̆ını, ayrıca, hükümetin bu tasarıyı hazırlarken, memleketin her türlü güvenliğini ve halkın hassasiyetlerini göz önünde bulundurduğunu, bu nedenle de bu konuda her hangi bir endişenin gereksiz olduğunu açıklamasıyla devam

${ }^{22}$ TBMM Z.C., D. 4, C. 17, 26.10.1933, Sira Sayısı: 363, s. 8.

${ }^{23}$ TBMM Z.C., D. 4, C. 17, 26.10.1933, s. 55.

${ }^{24}$ Afyon Karahisar mebusu Ali Bey kanun tasarısının acilen görüşülebilmesi için “...bu gün ayın 26'sıdır. Cumartesi günü misafirlerimiz gelecektir. Bu itibarla bugün bu kanunu çıkarabilirsek, o vatandaşlara da lazım olduğu vechle büyük bayramın atifetini göstermek imkanını vermiş olacağız. Bunun için bu kanun layihasının müstacelen müzakeresini sureti mahsusada rica ediyorum" cümleleriyle meclise bir önerge sunmuş ve bu önergede meclis tarafından kabul edilerek af kanunu tasarısının görüşülmesine derhal başlanmıştır. TBMM, Z.C., D. 4, C. 17, 26.10.1933, s. 51.

${ }^{25}$ TBMM Z.C., D. 4.C. 17, 26.10.1933, s. 51.

${ }^{26}$ TBMM Z.C.. D. 4, C. 17, 26.10.1933, s. 51 . 
etmiştir. ${ }^{27} \mathrm{Bu}$ açıklamanın hemen ardından, tasarının madde madde görüşülerek oylanması kabul edilmiştir.

Tasarının geneli hakkında fazla bir tartışma yaşanmazken, üzerinde durulan asıl nokta, İzmir suikastı tutuklularının affedilmesini öngören sekizinci madde olmuştur. Bilindiği gibi 17 Kasım 1925 yılında kurulan $\mathrm{TpCF}$, Şeyh Sait İsyanı sonrasında, programındaki "firkamız itikadı diniyeye ve fikriyeye hürmetkardır" maddesinden dolayı, sözü geçen isyandan sorumlu tutulmuş ve 5 Haziran 1925 'te kapatılmıştır.

Haziran 1926'da Mustafa Kemal'e karşı düzenlenen suikast girişiminin, muhalefet ve iktidar arsındaki gerginliğin tırmandığı bir dönemde planlanmış olması, olayı muhalefetin gerçekleştirdiği inancını kuvvetlendirmiş ve TpCF mensuplarından bir çoğu, olayla alakaları bulunduğu gerekçesiyle İstiklal Mahkemesinde yargılanmışlardır. İzmir İstiklal Mahkemesi'nin, 13-14 Temmuz 1926 tarihinde verdiği karara göre; pek çok kişi ölüm cezasına çarptırılmış, ${ }^{28}$ İttihat Terakki Hükümeti Maliye Nazırı Cavit Bey, Dr. Nazım ve Ardahan Mebusu Hilmi Beyler de Ankara İstiklal Mahkemesi kararıyla idam edilmişlerdir. ${ }^{29}$ Fırkanın kuruluşunu ilk başlatan isim olarak anılan ve Cumhuriyetin ilanından itibaren Mustafa Kemal'le aralarında soğuk rüzgarlar esen Rauf (Orbay) ve Adnan (Adıvar) Beyler gıyaplarında olmak üzere, Rahmi, Hüsnü, Ali Osman Vehbi ve İbrahim Ethem onar y1l sürgüne mahkum edilmişlerdir. ${ }^{30}$ Fakat, Adnan (Adıvar) Bey daha sonra devam eden mahkeme sonucunda dava ile bir ilgisi bulunmadığ ${ }_{1}$ gerekçesiyle, Terakkiperver Fırka kurucularından Kazım Karabekir, Ali Fuat (Cebesoy), Refet (Bele), Cafer Tayyar ve Mersinli Cemal Paşalarla, mebuslardan Faik, Sabit, Feridun Fikri, Kamil Zeki, Bekir Sami, Besim Necati, Münir Hüsrev, ve Gazetecilerden Hüseyin Cahit Yalçın'la beraber serbest bırakılmıştır. ${ }^{31}$ Rauf Bey ise zaten yurtdışında bulunduğu için, hakkındaki bu karar uygulanamamıştır. Şimdi ise bu cezaları almış olan kişilerden bazılarının affı Mecliste tartı̧ılmaktadır.

Urfa Mebusu Ali Saip Bey, bu kişilerin affına şiddetle karşı çıkmış, "Efendiler; yüz ellilikler İstanbul'da veyahut vatanin her hangi bir köşesinde vatana suikast etmek istiyorlardı. Bunların kimisi yazısı ile, kimisi sözï ile, Fakat İzmir suikastçıları bir vatanı öldürmek istediler...rica ederim bu

${ }^{27}$ TBMM Z.C., C. 17, 26.10.1933, s. 51 .

${ }^{28}$ İstanbul Mebusu İsmail Canbolat, Lazistan Mebusu Ziya Hurşit, Saruhan Mebusu Halis Turgut, Ayıcı Arif, İzmir Mebusu Şükrü, Erzurum Mebusu Rüştü (Paşa), Trabzon Mebusu Hafız Mehmet, Emekli Albay Baytar Rasim, Ankara Eski Valisi Abdülkadir, Abidin, Sarı Efe Edip, Gürcü Yusuf, Laz İsmail, Çopur Hilmi, Kara Kemal. Nurşen Mazıcı, Belgelerle Atatürk Döneminde Muhalefet (1919-1926), Dilmen Yayınevi, İstanbul, 1984, s. 156.

${ }^{29}$ Mete Tunçay, Türkiye'de Tek Parti Yönetiminin Kurulması (1923-1931), 3. Bask1, Cem Yayınevi, İstanbul, 1992, s. 166.

${ }^{30}$ Mazıc1, Belgelerle ..., s. 157.

${ }^{31}$ Mazıcı, Belgelerle..., s. 156-157. 
suikastçılar affedilir mi? Ben Umumi bir affı kabul ederim. Fakat bunları asla. Ne 150likler ne de bunlar. Asla affedilemez...biz bunlarl affedersek tarih bizi affetmez" sözleri, milletvekillerinin şiddetli alkışlarıyla desteklenmiştir. ${ }^{32}$ Meclisteki bu tepki karşısında bir konuşma yapan Dahiliye Vekili Şükrü Kaya Bey'in açıklamalarına göre; gerek Terakkiperver Fırka suçluları gerekse İzmir suikastı mahkumlarından, olaylarla doğrudan ilgisi olanlar zaten mahkemelerin arkasından idama mahkum edilmişler ve cezalarını görmüşlerdir. Bu kanunla affedilmek istenenler ise büyük cezalara çarptırılmış olanlar değildirler. Bu kişiler zaten cezalarının altı senesini çekmişlerdir. Kanuna göre üst sınır 10 sene olduğuna göre, cezalarının sadece, geri kalan 4 senesi affa uğramaktadır. Milletvekillerini bu maddenin kabulü için ikna eden en önemli etkenin ise, Şükrü Bey'in; konuşmasının devamında dile getirdiği; "Büyük Şef'in Büyük Gazi'nin" bu konuda göstermiş olduğu merhameti, kendine suikast yapmış olanların affedilmelerine olan isteğini Meclisten rica etmiş olduğunu anlatan sözleri olduğuna şüphe yoktur. ${ }^{33} \mathrm{Bu}$ konuşmanın ardından, yapılan oylama sonucunda sekizinci madde de kabul edilmiştir. ${ }^{34}$

$\mathrm{Bu}$ madde kapsamında affedilecek olanlardan Rauf Bey, hatıralarında; “...bu affin katiller ve şakilerle birlikte ben de şamil hükmünü kendi rızamla kabul edersem, bugüne kadar sirf şahsi hirs ve garaz yüzünden aleyhime yöneltilen isnat ve iftiraları ve bu arada Cumhurreisine karşı suikasta teşebbüs cürmünü kabul ve itiraf etmiş gibi bir duruma düşerim" sözleriyle, affı kabul etmediğini belirterek, muhalif tavrını sürdürmüştür. ${ }^{35}$

${ }^{32}$ TBMM Z.C., D. 4, C. 17, 26.10.1933, s. 53.

33 "Büyük Şefin; Büyük Gazi'nin bu husustaki merhametini de göz önüne almak lazımdır. Bizzat kendi şahsına yapılmış olan suikastın affedilmesi arzusunu öteden beri izhar etmektelerdi Bunu hükümetten istemişlerdir. Bünaenaleyh Büyük Şefin kendine has olan bu büyük atfetini kabul etmenizi rica derim", TBMM Z.C., D. 4, C. 17, 26.10.1933, s. 53.

${ }^{34}$ Dönemin karakteri ele alındığında, hakim olan Tek Parti rejiminde, Atatürk'ün aleyhine ve Hükümetin isteğine ters düşmek pek mümkün değildir. O dönemde TBMM, Cemil Koçak'ın ifadesiyle; "Hükümet faaliyetlerini belirleyen bir organ olmaktan çok, yönetime yardımcı olmayı asıl görev seçmiş bir organ niteliğindedir ve bu hali ile yönetimin aldı ̆̆ı kararların meşru hale gelmesine hizmet eden bir işlev görmektedir", Cemil Koçak, "Tek Parti Yönetimi, Kemalizm ve Şeflik Sistemi; Ebedi Şef/Milli Şef”, Modern Türkiye'de Siyasi Düşünce Serisi, Kemalizm, C. 2, İletişim Yayınları, İstanbul, 2001, s. 122.

${ }^{35}$ Rauf Orbay, Cehennem Değirmeni, C.II, Emre Yayınları, İstanbul, 1993, s. 237-239; Oysa ki, çıkarılan af kanununda mahkumlara affı ret hakkı tanınmamış olduğundan, hukuki olarak, Rauf Bey'in bu affı ret edebilme gibi bir hakkı söz konusu değildir. İlerleyen yıllarda, Rauf Bey altıncı devrede tekrar mebus seçildiği zaman CHP'nin Umum Reis Vekili tarafından yayınlanan bir beyannamede, Rauf Orbay'ın, İzmir İstiklal Mahkemesi tarafından hakkında verilmiş olan mahkumiyet kararının kaldırılması için başvurduğunu, fakat af kanunun araya girmesiyle, davanın yeniden görüşülmesinin mümkün olmadığı, fakat, eğer mahkemenin tekrarı mümkün olsaydı, kesinlikle beraat edeceği kanaatine varıldığı belirtilmiştir. Ali Fuat Cebesoy, Siyasi Hatıralar, C. II, Doğan Kardeş Yayınları, İstanbul, 1960, s. 216-217. 
Bir başka madde ise basın suçlarının affını öngören dokuzuncu maddedir. Serbest Cumhuriyet Firkasının kurulmasıyla beraber basında önemli tartışmalar yaşanmaya başlamıştır. Özellikle muhalefeti destekleyen basın kuruluşlarıyla iktidar yanlıları arasındaki gerginlikler, Serbest Fırkanın kendini feshetmesinin ardından yaşanan Menemen olayıyla giderek derinleşmiştir. 1931 tarihli Matbuat Kanunuyla basına önemli kısıtlamalar getirilmiștir. $^{36} 10$ Mayıs 1931 CHF Kurultayından sonra, parti devleti politikasıyla tüm çoğulcu kuruluşların denetim altına alınma sürecinde, bu yasayla basın da denetim altına alınmıştır. Fakat, Cumhuriyetin onuncu yıl kutlamalarında, Batı dünyasına gösterilmek istenen Türkiye'yle basına uygulanan sansür pek de bağdaşmamaktadır. Bu nedenle bir yumuşama yoluna gidilmiş ve kanunun ilgili maddesi düzenlenerek, basın suçlarının bir bölümüne af getirilmiştir. Adliye Encümeni, bu maddeyle, hükümete karş1 işlenen suçlardan doğrudan doğruya savcılar tarafından takibat yapılarak mahkum edilenler veya tahtı zanda bulunanların kesin olarak affedildiğini, fakat şahsi davalar için böyle bir kesinliğin söz konusu olmadığını açıklamıştır. ${ }^{37}$

Cumhuriyetin Onuncu yılı şerefine çıkarılan bu geniş kapsamlı af kanununun dikkate değer bir yönü de, Milli Mücadele döneminde Anadolu hareketini baltalayacak hareketlere girişenlere yönelik alınan kararlardır. Buna göre, Hilafetin kaldırılmasına ve Osmanlı Hanedanının Türkiye sınırları dışına çıkarılmasına yönelik olan, 431 numaralı kanunda yazılı şahıslar ile Lozan Anlaşmasında bir protokolle belirlenen 150 kişinin aftan yararlanamayacakları açıkça belirtilmiş ${ }^{38}$ ve bu madde, üzerinde hiçbir tartışma yapılmadan aynen kabul edilmiştir. ${ }^{39}$

${ }^{36} \mathrm{Bu}$ kısıtlamalardan bazıları; Gazete ve dergi sahiplerinde Vatan, ulusal savaş, Cumhuriyet ve devrim aleyhinde bulunup da her hangi bir divan, mahkeme tarafından mahkum olmamak, ulusal savaşta işgal altında düşman emellerine hizmet edici yayın yapmış olmamak, Padişah ve hilafetçilik yolunda ve komünistlik ve anarşistliğe kışkırtan yayın yapılamaz, 3 Mart 1924 tarih ve 431 sayılı yazıyla Türkiye Cumhuriyeti sınırlarına çıkarılmış olanlarla 16 Nisan 1924 tarih ve 481 sayılı af kanununun 3. Maddesinde yazılı kişilerin gönderdikleri yazıları yayınlamak yasaktır. Mazıcı, "1930'a Kadar Basının Durumu ve 1931 Matbuat Kanunu”, Atatürk Yolu, Y. 9, C. 5, S. 19, Ankara, 1996, s. 148.

${ }^{37}$ TBMM Z.C., D. 4, C. $17,26.10 .1933$, s. 54.

${ }^{38}$ TBMM Z.C., D. 4, C. 17, 26.10.1933, s. 56.

${ }^{39}$ Tevfik Rüştü Aras'ın aktardığı iddia edilen bilgiye göre; Atatürk, bu af kanunundan istisna edilen 150 kişinin affını, henüz bu kanun hazırlanırken, hükümetten istemiş, fakat Başvekil İsmet Paşa ve Dahiliye Vekili Şükrü Kaya Bey, Atatürk'ün bu isteğini olumlu karşılamamışlardır. Kutay, s. 16; İlhami Soysal, s. 106 Feridun Kandemir de Atatürk'ün bu girişimine karşı, başta İsmet Paşa olmak üzere bir çok kişinin, bazı mahzurlar ileri sürerek, bu kişilerin affının henüz zamanı olmadığını söylediklerini ve bu girişimi tasvip etmediklerini belirtmiştir. Feridun Kandemir, Istiklal Savaşında Bozguncular ve Casuslar, Yakın Tarihimiz Yayınları, İstanbul, 1964 s. 179 Böylece 150'liklerin affı konusu 1938 yılının Haziranına kalmıştır. 
Cumhuriyetin onuncu yılı șerefine hazırlanmıș olan, af kanunu tasarısı, maddelerin görüşülmesinin ardından yapılan oylamayla, Meclisin 26 Ekim 1933 tarihli 76. Birleşiminin ikinci oturumunda kabul edilmiştir. ${ }^{40}$

Af kanunu tasarısının Meclis tarafından kabul edildiği haberi, dönemin gazeteleri tarafından halka duyurulmuştur. ${ }^{41}$ Daha çok Cumhuriyetin onuncu yılı kutlamalarının gölgesinde kalmış olan yasa, genellikle, kanundan kimlerin yararlanacağı açıklamalarına yer vermiş ve hükümetin halkına bahşettiği bir lütuf olarak değerlendirilmiştir. 27 Ekim 1933 tarihli Hakimiyet-i Milliye Gazetesi, tasarının kanunlaştığg haberini verdikten sonra; Meclis görüşmelerinden alıntılar yaparak, yağmacılık, yol kesmek, ev basmak gibi suçların affın dışında tutulduğunu duyurmuştur. Gazete kabul edilen yasa tasarısı hakkında; "Kazaen ve hataen veya herhangi bir zaruret icabı işlenen suçlar bir defa olmak üzere ilerde ıslahı hal eder ümidinde bulunan cürümler için bir aftır" değerlendirmesini yapmıştır. ${ }^{42} \mathrm{Bu}$ af kanunuyla rüşvet suçlarının, 150liklerin ve iki defa mahkum olmuş olanların affın dışında tutulacakları da basın aracılığıyla halka duyurulmuştur. ${ }^{43}$ Akşam gazetesi; İstanbul'da 700 mahkumun serbest bırakılacağını yazarken, ${ }^{44}$ Milliyet gazetesi de 150 mahkum ve 400 kadar mevkufun tahliye edileceği haberini vermektedir. ${ }^{45}$ Milliyet gazetesinde yer alan; Hürriyet havasına kavuşanların çıkarken "yaşasın Cumhuriyet" diye bağırdıkları şeklindeki haber ise dönemin coşkusunu göstermek açısından oldukça önem arz etmektedir. ${ }^{46}$

Dönemin basını, özellikle Terakkiperver Fırka mensupları ve İzmir suikastçılarının affı üzerinde yorumlar yapmakta ve bu yasa çerçevesinde affedilecek olan Rauf Orbay'la ilgili haberler vermektedirler. Bu haberlerde; Rauf Bey'in yurt dışında yaşadığı ve bu kanun çerçevesinde yurda dönüp dönmeyeceği merak konusu yapılmıştır. TpCF mensupları ile İzmir Suikastı mahkumlarının affedilmesine ilgi gösteren basının, 150'likler hakkında dikkate değer bir değerlendirme yapmamalarının sebebini, hem bahsi geçen 150 kişinin hainliklerinin meşruiyetini koruması, hem de Takrir-i Sükun Kanununun 1929 'da yürürlükten kaldırılmıs olmasına rağmen basın özgürlüğünü kısıtlayan 25 Temmuz 1931 tarihli Matbuat Kanununun sonrasında çok sayıda gazetecinin tutuklanmış olmasına bağlayan görüşler mevcuttur. ${ }^{47^{7}}$ Ayrıca, 150'liklerden bazılarının, yurt dışında Türkiye

${ }^{40}$ TBMM Z.C., D. 4, C. 17, 26.10.1933, s. 57; Düstur, D. 3, C. 14'ün Devamı, Kanun No: 2330 , s. $1803-1806$

${ }^{41}$ Hakimiyet-i Milliye, 27 Ekim 1933, Akşam, 27 Ekim 1933, Cumhuriyet, 27 Ekim 1933, Milliyet, 27 Ekim 1933.

${ }^{42}$ Hakimiyet-i Milliye, 27 Ekim 1933.

${ }^{43}$ Akşam, 26 Ekim 1933.

${ }^{44}$ Akşam, 28 Ekim 1933.

${ }^{45}$ Milliyet, 27 Ekim 1933.

${ }^{46}$ Milliyet, 29 Ekim 1933.

${ }^{47}$ Mazıcı, "1930'a Kadar ...", s. 147-150. 
aleyhindeki tavırlarını devam ettirmeleri, ${ }^{48}$ bu kişilerin affına sıcak bakılmamasının ve basında da haklarında her hangi bir yorum yapılmamasının nedenleri arasında sayılabilir.

Sonuç olarak; Cumhuriyetin Onuncu yıldönümü kutlamalarının halkta yarattığı büyük coşku törenlere damgasını vurmuş, on yıl gibi kısa bir sürede çok uzun bir yol kat etmiş olan Cumhuriyet, başarısını bu kutlamalarla bütün dünyaya göstermiştir. Cumhuriyetin onuncu yılı şerefine çıkarılan af kanunuyla da uluslar arası alanda kendini kanıtlama çabasında olan genç Cumhuriyet, yabancı devletlere Türk Devletinin kimseden korkusunun olmadı̆̆ 1 ve Cumhuriyetin geçen yıllar içerisinde son derece sağlam temellere kavuştuğunu göstermek arzusuyla hareket etmiştir. Bu af kanunuyla; özellikle Tek Partili rejimin kurulması döneminde yaşanan katı uygulamaların unutulması ve devletle halk arasında bir yakınlaşmanın sağlanmasına çalışılmı̧ ve af yasası bu yönüyle 1933 yılı öncesinde yaşanan siyasi çalkantılar sonrasında, dönemin normale dönmesini sağlayan bir araç olarak kullanılmıştır.

\section{KAYNAKÇA}

Akşam

Atatürk'ün Tamim, Telgraf ve Beyannameleri, C. IV, Atatürk Araştırma Merkezi Yayını, Ankara, 1991.

Bingöl, Sedat, Yüzellilikler Meselesi, Yayınlanmamış Yüksek Lisans Tezi, Hacettepe Üniversitesi, Atatürk İlkeleri ve İnkılap Tarihi Enstitüsü, Ankara, 1994.

Cebesoy, Ali Fuat, Siyasi Hatıralar, C. II, Doğan Kardeş Yayınları, İstanbul, 1960.

Cumhuriyet

Düstur

Hakimiyet-i Milliye

Kandemir, Feridun, İstiklal Savaşında Bozguncular ve Casuslar, Yakın Tarihimiz Yayınları, İstanbul, 1964.

Keyman, Selahattin, Türk Hukukunda Af, Genel f-Özel Af, Ankara, 1965.

Koçak, Cemil, "Tek Parti Yönetimi, Kemalizm ve Şeflik Sistemi; Ebedi Şef/Milli Şef", Modern Türkiye'de Siyasi Düşünce Serisi, Kemalizm, C. 2, İletişim Yayınları, İstanbul, 2001.

Kutay, Cemal, 150'likler Faciası, Sıralar Matbaası, İstanbul, 1955.

${ }^{48}$ Bingöl, s. 201-211. 
Mazıcı, Nurşen, Belgelerle Atatürk Döneminde Muhalefet (1919-1926), Dilmen Yayınevi, İstanbul, 1984.

“1930'a Kadar Basının Durumu ve 1931 Matbuat Kanunu”, Atatürk Yolu, Y. 9, C. 5, S. 19, Ankara, 1996.

, “Af Yasalarında 150'likler”, Ankara Üniversitesi Siyasal Bilgiler

Fakültesi Dergisi, C. 55, S. 1, Ankara, Ocak-Mart 2000.

Milliyet

Orbay, Rauf, Cehennem Değirmeni, C.II, Emre Yayınları, İstanbul, 1993.

Soysal, İlhami, 150likler, Gür Yayınları, İstanbul, 1985.

Soysal, İsmail, Tarihçeleri ve Açıklamaları İle Birlikte Türkiye'nin Siyasal Antlaşmaları, C. I (1920-1945), 2. Baskı, Türk Tarih Kurumu Yayını, Ankara, 1989.

Tunçay, Mete, Türkiye'de Tek Parti Yönetiminin Kurulması (1923-1931), 3. Baskı, Cem Yayınevi, İstanbul, 1992.

Türkiye Büyük Millet Meclisi Zabit Ceridesi

Yılmaz, Mustafa, İngiliz Basını ve Atatürk'ün Büyük Türkiyesi, Phoenix Yayınları, Ankara, 2002. 